\title{
Does Environmental Regulation Promote Green Technology Innovation in Chinese Manufacturing?
}

\author{
Jingjing Liu ${ }^{1,2 *}$, Ming Zhao \\ ${ }^{1}$ School of Business Administration, Anhui University of Finance and Economics, Bengbu, China \\ ${ }^{2}$ Business School, Hohai University, Nanjing, China \\ Email: ${ }^{\star 19085980 @ q q . c o m, ~ z h a o m i n 3451 @ s i n a . c o m ~}$
}

How to cite this paper: Liu, J.J. and Zhao, M. (2020) Does Environmental Regulation Promote Green Technology Innovation in Chinese Manufacturing?. Open Access Library Journal, 7: e6532.

https://doi.org/10.4236/oalib.1106532

Received: June 16, 2020

Accepted: July 4, 2020

Published: July 7, 2020

Copyright $\odot 2020$ by author(s) and Open Access Library Inc.

This work is licensed under the Creative Commons Attribution International License (CC BY 4.0).

http://creativecommons.org/licenses/by/4.0/ (c) (i) Open Access

\begin{abstract}
The Porter Hypothesis states that environmental regulation promotes technological innovation among enterprises, thereby supporting economic growth. However, whether the hypothesis is valid in China remains to be tested. To assess this, we construct an environmental regulation panel model to assess the impact of regulation on green technology innovation, examining data from 27 manufacturing industries in China from 2006 to 2015. Based on extant research results on environmental regulation and technological innovation in China and abroad, we divide green technology innovation into green product innovation and green process innovation as the dependent variables, using environmental regulation as the independent variable and total industry profits and innovative human resources as the control variables. Our results show that at this stage, for the 27 industries, the implementation of strict environmental regulations has inhibited both green process innovation and green product innovation. The result verifies that the Porter Hypothesis is not valid in the current Chinese manufacturing environment.
\end{abstract}

\section{Subject Areas}

Environmental Economics

\section{Keywords}

Environmental Regulation, Green Technology Innovation, Green Product Innovation, Green Process Innovation

\section{Introduction}

For many years, economic growth and development in emerging market econ- 
omies has depended largely on high input of resources, high-energy consumption, high emissions, and low quality, efficiency, and output. This extensive industrial growth mode has not made a significant contribution to economic growth for some time now. Moreover, it has increased energy consumption, environmental pollution, and polluting emissions. After more than 30 years of rapid development, China has become the world's second largest economy with many world-renowned achievements. However, this development has been accompanied by huge costs in terms of energy, the environment, and social welfare. China has surpassed the United States as the world's largest polluter. As a large manufacturing country, China plays an important role in global economic growth, but the negative impact on energy and the environment cannot be ignored.

For example, today, China's air pollution is getting worse while its energy consumption is increasing. According to statistical data released by the Communiqué on the State of China's Eco-Environment in 2018, China's total national energy consumption in 2018 was 4.64 billion tons of standard coal, an increase of $3.3 \%$ over 2017. Of this, coal consumption increased by $1.0 \%$ and accounted for $59.0 \%$ of total energy consumption. This reflects how China's economic growth is still energy resource driven. The high level of emissions and pollution, together with high input consumption of China's manufacturing industry, has placed tremendous pressure on China's resources and on the environment. Moreover, these issues have increasingly become the focus of global attention.

Therefore, it is critical that China improves its manufacturing energy efficiency and reduces pollution and emissions. With the growing popularity of the concepts of greening and ecologicalization, green technological innovation has become a central way to control environmental pollution as well as improve resource utilisation efficiency and the quality of industrial growth [1]. Although the Porter Hypothesis states that environmental regulation plays a positive role in green technology innovation, its premise has not been fully validated, and existing research still presents differing views. Moreover, the hypothesis is yet to be validated in China.

From the perspective of industry heterogeneity, this paper analyses the impact of environmental regulation on green technology innovation in various manufacturing industries. We contribute to the literature by formulating industry-specific environmental regulation policies for China to reduce environmental pollution and improve resources for Chinese manufacturing. In addition, we provide guidance for improving the quality of economic growth. The rest of the paper is organised as follows: Section 2 briefly reviews the literature that forms the basis for the research questions. Section 3 mainly describes the model specification and the data. In Section 4, the empirical approach is described and empirical results provided. The last section provides a summary and conclusion of the main results.

\section{Literature Review}

At present, the academic community has differing views on the relationship be- 
tween environmental regulation and green technology innovation. One view is that environmental regulation promotes green technological innovation among enterprises. The most representative example is the American scholar Porter [2], who hypothesised that appropriate environmental regulations can stimulate technological change in enterprises, which will produce innovative compensation effects in the long run, thereby reducing costs and enhancing corporate competition. Through empirical analysis of 37 industrial firms, Yu Wei et al. [3] confirmed that environmental regulations can promote technological innovation among industrial enterprises. Li Wanhong et al. [4] analysed panel data of 16 pollution-intensive industries in China and found that (while taking certain control variables into account), the government's strict environmental regulations can effectively promote green technology innovation in pollution-intensive industries.

A second view is that environmental regulation increases corporate costs and crowds out corporate resources, thereby hindering companies from implementing green technological innovation. For example, Levinsohn and Petrin [5] examined the paper industry in the United States and found that the cost of pollution control was at very high while productivity was relatively low for a long time, implying that the United States' strict environmental regulations reduced productivity in its paper industry. Slater and Angel [6] also found that under high-intensity environmental regulations, the overall R\&D level of a company decreased, and the innovation effect produced by its R\&D barely made up for its cost. Wagner [7] found that the level of implementation of environmental regulations among German manufacturing companies showed a negative correlation with their overall patent applications. Ramanathan [8] analysed 16 industrial sectors in the United Kingdom by constructing a structural equation model and found that in the short term, environmental regulations inhibited technological innovation.

The Chinese scholar Zhao Xikang [9] believes that environmental regulation is essentially the internalisation of the external costs of the environment. By increasing the price of products, companies pass on costs such as sewage charges and environmental damage management costs to consumers, which leads to the decrease of market demand for these enterprises' products, thus reducing the competitiveness of enterprises and further weakened their technological innovation capabilities. Through empirical analysis of China's provincial panel data, Xie'e [10] found that environmental regulations inhibited the production-technological progress of enterprises.

A third view indicates that there is uncertainty about the impact of environmental regulations on green technology innovation. Lanoie, Patry, and Lajeunesse [11] analysed data of 17 Canadian manufacturing industries from 1985 to 1994 and found that in the long run, environmental regulations had a positive impact on productivity, but a negative impact in the short term. Liu et al. [12] analysed panel data of 17 industrial enterprises in 30 provinces (municipalities, 
autonomous regions) and pointed out that the impact of environmental regulations on production technology progress in different industries differed. Some industries showed a significant inverted or U-shaped relationship, while there was no significant relationship in other industries. Jiang et al. [13] pointed out that the relationship between the intensity of environmental regulation and the technological progress of industrial enterprises in Jiangsu Province was neither a simple linear relationship nor a $\mathrm{U}$-shaped one, but rather, a polyline correspondence. That is, when the intensity of environmental regulation is less than a certain threshold value, environmental regulation will inhibit the progress of production-technology; when the intensity of environmental regulation exceeds the threshold value, the inhibition effect begins to decrease, but does not show a positive promotional effect.

Looking at the extant literature, we find that scholars have studied the relationship between environmental regulation and green technology innovation from different perspectives, but there are still deficiencies. First, most of the previous literature focuses on industrial enterprises, manufacturing, or individual industries. Within the research on the impact of environmental regulations on the progress of production technology, there are few studies that classify industries and analyse the impact according to the degree of the pollution of different industries. Second, most studies focus on environmental regulation and general technological innovation but there is scant research on environmental regulation and its impact on green technological innovation.

Here, we divide green technological innovation into two dimensions: green product innovation and green process innovation. We then select panel data from 2006 to 2015 by examining 27 manufacturing industries to analyse the impact of environmental regulations on green product innovation and green process innovation. Our aim is to provide support for formulating new policies for China to promote the green sustainability of manufacturing development and to provide recommendations.

\section{Model Construction and Data Source}

\subsection{Model Construction}

Green technological innovation (GTI) refers to technological innovation based on the product life cycle, strictly obeying the laws of the ecological economy at each stage of the innovation process while minimising the total cost of the products [1]. According to the perspective of the environmental economics school, GTI includes externalities. However, the market mechanism alone cannot completely solve the externalities of environmental problems. It is difficult to achieve the effect of ecological compensation, the optimal allocation of resources, and maximise social welfare. Thus, the government formulates environmental regulatory policies to address externalities and rectify the economic behaviour of the regulated entities [14].

According to OECD classification [15], green technology innovation can be 
divided into green product innovation (GPTI) and green process innovation (GPSI) from the perspective of the objective of technology implementation. Therefore, the impact of environmental regulation on GTI can be further divided into the impact of environmental regulation on GPTI and GPSI. GPTI and GPSI are the dependent variables in our paper and environmental regulation (ER) is the independent variable. Moreover, to ensure the robustness of the research results, other factors affecting GTI need to be added as control variables. According to Sterner and Turnheim [16], total industry profit (Tp) and innovative human resource input (IMI) are the main factors affecting green technology innovation. Therefore, these two factors are selected as control variables.

Based on this, the following panel data models are established. Model (1) and Model (2) represent the impact of environmental regulation on GPSI and GPTI, respectively.

In this paper, logarithmic processing is performed on some variables ${ }^{1,2}$. Our purpose is to reduce the volatility of the data and alleviate the multicollinearity between variables and the heteroscedasticity of the equation.

Model 1: $\quad \operatorname{lnGPSI}_{\mathrm{it}}=\alpha_{\mathrm{i}}+\beta_{1} \mathrm{ER}_{\mathrm{it}}+\beta_{2} \operatorname{lnIMI}_{\mathrm{it}}+\beta_{3} \operatorname{lnT} \mathrm{p}_{\mathrm{it}}+\varepsilon_{\mathrm{it}}$.

Model 2: $\quad \operatorname{lnGPTI} I_{\text {it }}=\alpha_{\mathrm{i}}+\beta_{1} \mathrm{ER}_{\mathrm{it}}+\beta_{2} \operatorname{lnIMI}_{\mathrm{it}}+\beta_{3} \ln \mathrm{Tp}_{\mathrm{it}}+\varepsilon_{\mathrm{it}}$.

In the models: lnGPSI represents the logarithm of the GPSI index, lnGPTI represents the logarithm of the GPTI index, ER represents environmental regulation, $\operatorname{lnTp}$ represents the logarithm of the total industry profit index, lnIMI represents the logarithm of innovative human resource investment, $\alpha$ represents the intercept term, $\beta$ represents the estimation parameter, i represents the manufacturing industry, $\mathrm{t}$ represents time (2006-2015), and $\varepsilon$ represents the error term. The specific meaning and measurement method of each variable is as follows.

Dependent variables. GPSI refers to the effective reduction of the generation and discharge of pollutants and the reduction of environmental pollution through the development and introduction of new equipment, new technologies, and/or the upgrading and reconstruction of existing process equipment. As GPSI is mainly focused on the development and introduction of green processes and equipment in the production process, or the renovation and renewal of existing equipment, this paper draws on the views of $\mathrm{Bi}$ [17] and other similar methods. Thus, we use the sum of internal R\&D expenditures and technological transformation expenditures to measure GPSI.

GPTI means that in line with the trend of green and sustainable development, products meet not only the functional needs of consumers, but also environmental protection requirements in the R\&D process. In design and production,

\footnotetext{
${ }^{1}$ As environmental regulation (ER) data does not fluctuate significantly and the values will be negative after taking the logarithm, we do not use logarithmic processing for ER.

${ }^{2}$ The profits of some industries are negative. Taking the logarithm directly will generate missing values. This paper uses the log-modulus transformation method proposed by John and Draper (1980) to logarithmically convert the profit. The formula is $\mathrm{X}=\operatorname{sign}(\mathrm{x}) * \log (|\mathrm{x}|+1)$.
} 
they achieve low consumption and high efficiency for saving resources and energy and reducing environmental pollution. Compared with traditional product innovation, GPTI pays more attention to energy saving and consumption reduction in the production, packaging, and transportation of green products. Therefore, this paper uses the ratio of new product sales revenue to energy consumption as the proxy measure for green product innovation; the larger the ratio, the higher the degree of GPTI.

Independent variables: There is currently no consensus in the academic community regarding an indicator for environmental regulation. Some studies have measured the strength of environmental regulation from the perspective of environmental regulation policies. For example, Smarzynska and Wei [18] proposed that the effect of environmental regulations could be examined by the number of government-promulgated policies and regulations, or by comparing the amount of environment pollutant emissions before and after the implementation of government policies. Other studies have measured it from the perspective of the cost of pollution control. Fredriksson and Millimet [19] proposed that the strength of environmental regulation could be measured by the total cost of treating wastewater, exhaust gas, and solid waste, or the ratio of pollution investment to the total cost or output value of the enterprise. The larger the total cost or ratio, the stricter the environmental regulations. Moreover, a research stream has focused on the perspective of pollution intensity. For example, Cole and Elliott [20] used the ratio of environment pollutant emissions to total output value of industrial firms to measure the strength of environmental regulations.

Our paper draws on the practice of Nie Guoqing [21] and other methods. Here, we adopt the perspective of pollution control costs, using the ratio of pollution control costs to total costs to measure the strength of environmental regulations. The cost of pollution control is measured by the sum of the annual operating cost of wastewater and waste-gas treatment facilities in various firms in the manufacturing industry. The total cost includes the cost of main operations and the cost of pollution control. The larger the value of this indicator, the higher the intensity of the environmental regulations facing the company.

Control variables. This paper selects total profit (Tp) as a control variable (as total profit can measure the size and profitability of the enterprise) and the total profit of the manufacturing industry as the proxy variable. With reference to $\mathrm{Li}$ Wanhong's [4] approach, the input of innovative human resources is another control variable. Innovative human resources input (IMI) refers to the input of personnel engaged in innovation activities in various industries. In a general sense, the more the investment in innovative human resources, the more effective the industry's green technology innovation, resulting in a reduction in pollutant emissions. Therefore, to express investment in innovative human resources, this paper uses the proportion of scientific and technological personnel to all employees; data are taken from enterprises that are bigger than the average for the designated industry. The definition of each variable is shown in Table 1. 
Table 1. Variable description.

\begin{tabular}{|c|c|c|}
\hline Variable name and unit & Variable symbol & Variable explanation \\
\hline $\begin{array}{l}\text { Green product innovation } \\
\text { (yuan/ton of standard coal) }\end{array}$ & GPTI & $\begin{array}{l}\text { Ratio of new product sales to } \\
\text { energy consumption }\end{array}$ \\
\hline $\begin{array}{l}\text { Green process innovation } \\
\quad(100 \text { million yuan })\end{array}$ & GPSI & $\begin{array}{l}\text { Sum of internal expenditure for } \mathrm{R} \& \mathrm{D} \\
\text { and investment for technological } \\
\text { transformation }\end{array}$ \\
\hline $\begin{array}{c}\text { Environmental regulations } \\
(\%)\end{array}$ & ER & $\begin{array}{l}\text { Pollution control cost as a } \\
\text { percentage of total cost }\end{array}$ \\
\hline $\begin{array}{c}\text { Total profit } \\
(100 \text { million yuan })\end{array}$ & $\mathrm{Tp}$ & $\begin{array}{l}\text { Total profit of various } \\
\text { manufacturing industries }\end{array}$ \\
\hline $\begin{array}{l}\text { Investment in innovative } \\
\text { human resources }(\%)\end{array}$ & IMI & $\begin{array}{l}\text { Proportion of scientific and technological } \\
\text { personnel of industrial enterprises above } \\
\text { a designated size to all employees }\end{array}$ \\
\hline
\end{tabular}

\subsection{Industry Choice and Data Source}

Because different industries have different pollution intensities, environmental regulations have different effects. Therefore, referring to the practice of Ren et al. [22] this paper classifies China's manufacturing into industries with severe pollution, moderate pollution, and light pollution. Due to differences in statistical classification, the naming of manufacturing industries around 2011, and the lack of data on some industries (such as electronics and communication equipment manufacturing, which were excluded), the research sample covered 27 industries. The specific classifications are shown in Table 2.

The data used in this paper are from the China Statistical Yearbook (2006-2015), the China Industrial Economic Statistical Yearbook (2006-2015), the Statistical Yearbook of Scientific and Technological Activities of Industrial Enterprises (2006-2015), and the China Environmental Yearbook (2006-2015).

\section{Empirical Analysis and Results}

\subsection{Descriptive Statistics and Stationarity Tests}

The paper uses Stata 15.0 software to analyse the panel data of 27 manufacturing industries in China. The description of the main variables is shown in Table 3. It can be seen from Table 3 below that the maximum value of environmental regulations is 0.990984 , the minimum value is 0.205711 , the average value is 0.8271936 , and the standard deviation is 0.1654891 . Thus, the gap between the maximum value and the minimum value is not very large, and the average value is high. It shows that the state has little difference in the implementation of environmental regulations in various industries in the manufacturing industry, and the implementation of environmental regulations in various industries is relatively strong.

The data in the panel model must be in a stationary sequence. If they are in a non-stationary sequence, a false regression problem will occur. Therefore, to 
Table 2. Classification of manufacturing industries.

\begin{tabular}{|c|c|c|c|}
\hline Pollution type & Industry & Pollution type & Industry \\
\hline Severe pollution & $\begin{array}{l}\text { Smelting and pressing } \\
\text { of ferrous metals }\end{array}$ & \multirow{14}{*}{ Light pollution } & Metal products industry \\
\hline \multirow{13}{*}{ Moderate pollution } & Paper and paper products & & $\begin{array}{l}\text { Leather, fur, down, } \\
\text { and its products }\end{array}$ \\
\hline & $\begin{array}{l}\text { Non-metallic mineral } \\
\text { products industry }\end{array}$ & & $\begin{array}{l}\text { Rubber and plastic } \\
\text { products }\end{array}$ \\
\hline & $\begin{array}{l}\text { Chemical raw materials } \\
\text { and chemical products } \\
\text { manufacturing }\end{array}$ & & $\begin{array}{l}\text { Printing industry, } \\
\text { reproduction of } \\
\text { recording media }\end{array}$ \\
\hline & $\begin{array}{l}\text { Non-ferrous metal smelting } \\
\text { and rolling processing } \\
\text { industry }\end{array}$ & & $\begin{array}{c}\text { Instrumentation and } \\
\text { cultural office supplies } \\
\text { machinery manufacturing }\end{array}$ \\
\hline & $\begin{array}{c}\text { Beverage } \\
\text { manufacturing }\end{array}$ & & $\begin{array}{l}\text { Special equipment } \\
\text { manufacturing }\end{array}$ \\
\hline & $\begin{array}{l}\text { Chemical fibre } \\
\text { manufacturing }\end{array}$ & & $\begin{array}{l}\text { Transportation equipment } \\
\text { manufacturing }\end{array}$ \\
\hline & $\begin{array}{l}\text { Petroleum processing, } \\
\text { coking and nuclear fuel } \\
\text { processing industries }\end{array}$ & & $\begin{array}{l}\text { Crafts and other } \\
\text { manufacturing }\end{array}$ \\
\hline & Textile industry & & $\begin{array}{l}\text { General Equipment } \\
\text { Manufacturing }\end{array}$ \\
\hline & $\begin{array}{l}\text { Agricultural and sideline } \\
\text { food processing industry }\end{array}$ & & $\begin{array}{l}\text { Apparel and other fibre } \\
\text { products manufacturing }\end{array}$ \\
\hline & Food manufacturing & & $\begin{array}{l}\text { Tobacco processing } \\
\text { industry }\end{array}$ \\
\hline & $\begin{array}{l}\text { Pharmaceutical } \\
\text { manufacturing }\end{array}$ & & $\begin{array}{c}\text { Furniture } \\
\text { manufacturing }\end{array}$ \\
\hline & \multirow[t]{2}{*}{$\begin{array}{l}\text { Wood processing and } \\
\text { bamboo and rattan } \\
\text { palm products }\end{array}$} & & $\begin{array}{l}\text { Culture, education, sporting } \\
\text { goods manufacturing }\end{array}$ \\
\hline & & & $\begin{array}{l}\text { Electrical machinery and } \\
\text { equipment manufacturing }\end{array}$ \\
\hline
\end{tabular}

Table 3. Description of the main variables.

\begin{tabular}{cccccc}
\hline Variable & Obs. & Mean & Std dev. & Min. & Max. \\
\hline lnGPSI & 270 & 14.14523 & 1.327095 & 11.06954 & 17.4336 \\
$\ln$ GPTI & 270 & 8.506433 & 1.383977 & 3.441759 & 11.19954 \\
ER & 270 & 0.8271936 & 0.1654891 & 0.205711 & 0.990984 \\
$\ln I M I$ & 270 & 5.334265 & 1.002709 & 2.800039 & 11.13335 \\
$\ln T p$ & 270 & 6.664159 & 1.5044 & -6.911887 & 8.776139 \\
\hline
\end{tabular}


ensure the validity of the estimation, we apply the LLC and ADF-Fisher tests to assess the stationarity of each variable. The test results are shown in Table 4 . The results show that there are no unit roots for the variables in the sample; that is, all variables are stationary sequences.

\subsection{Empirical Analysis Results}

Because the panel data are two-dimensional, if the model is incorrectly set or the estimation method is selected incorrectly, the results will be biased. Therefore, we need to test the mode of the model before using the panel data for regression. To eliminate individual effects, in-group estimations (including fixed effects and random effects) are standard estimation methods of panel data models. This paper uses the Hausman test to determine whether to choose a random effect model or a fixed effect model. If the Hausman test value is significant, a fixed effect model is preferred; otherwise, a random effect model is chosen.

\subsubsection{Impact of Environmental Regulations on GTI}

As can be seen in Table 5, for the entire manufacturing industry, the influence coefficient of environmental regulation on the logarithm of GPSI is -1.1393, and has passed the $1 \%$ significance level test. The influence coefficient of environmental regulation on the logarithm of GPTI is -0.7591 , and has passed the $10 \%$ significance level test, indicating that for every unit of environmental regulation improvement, the GPSI and GPTI of enterprises will be reduced by $1.1393 \%$ and $0.7591 \%$. Therefore, environmental regulations have had a significant negative inhibitory effect on both GPSI and GPTI in the sample period. That is, the stricter the environmental regulations, the harder it is for the manufacturing industry to carry out green process technology transformation and equipment updates, and/or to develop and produce new green, energy-saving products. Therefore, for various industries in China's manufacturing industry, the Porter Hypothesis does not apply and the innovation compensation theory fails. This may be because a large amount of capital investment is needed for enterprises to carry out technological innovation, and with stricter environmental regulations, the cost of pollution control increases, squeezing out funds for investment in

Table 4. Data stationarity test.

\begin{tabular}{cccc}
\hline Variable & $\begin{array}{c}\text { LLC inspection } \\
\text { Adjusted t value }\end{array}$ & ADF-Fisher test P & Conclusion \\
\hline $\ln$ GPSI & $-2.3318^{* * *}$ & $88.1815^{* * *}$ & Stationary \\
$\ln$ GPTI & $-3.8778^{* * *}$ & $101.8395^{* * *}$ & Stationary \\
ER & $-5.0748^{* * *}$ & $138.6623^{* * *}$ & Stationary \\
$\operatorname{lnIMI}$ & $-4.4801^{* * *}$ & $120.4449^{* * *}$ & Stationary \\
$\ln \mathrm{-}$ - & $11.5927^{* * *}$ & $10.8458^{* * *}$ & Stationary \\
\hline
\end{tabular}

Note: ${ }^{*}{ }^{* *}$, and ${ }^{* * *}$ represent significance levels at $10 \%, 5 \%$, and $1 \%$, respectively. 
Table 5. Empirical measurement results.

\begin{tabular}{|c|c|c|c|c|c|c|c|c|}
\hline \multirow{2}{*}{ Variable } & \multicolumn{2}{|c|}{$\begin{array}{l}\text { Full Sample of } \\
\text { Manufacturing }\end{array}$} & \multicolumn{2}{|c|}{$\begin{array}{l}\text { Severely Polluted } \\
\text { Industry }\end{array}$} & \multicolumn{2}{|c|}{$\begin{array}{l}\text { Moderately Polluted } \\
\text { Industry }\end{array}$} & \multicolumn{2}{|c|}{$\begin{array}{l}\text { Slightly Polluted } \\
\text { Industry }\end{array}$} \\
\hline & model (1) & model (2) & model (1) & model (2) & model (1) & model (2) & model (1) & model (2) \\
\hline ER & $\begin{array}{c}-1.1393^{* * *} \\
(-4.16)\end{array}$ & $\begin{array}{c}-0.7591^{\star} \\
(-1.8)\end{array}$ & $\begin{array}{c}-2.0608^{*} \\
(-2.1)\end{array}$ & $\begin{array}{c}-4.4080 \\
(-0.9)\end{array}$ & $\begin{array}{c}-2.3066^{* * *} \\
(-4.11)\end{array}$ & $\begin{array}{c}-0.9614 \\
(-1.3)\end{array}$ & $\begin{array}{c}-0.2365 \\
(-0.9)\end{array}$ & $\begin{array}{l}-0.21 \\
(-0.8)\end{array}$ \\
\hline $\operatorname{lnIMI}$ & $\begin{array}{c}0.3499^{\star * *} \\
(8.06)\end{array}$ & $\begin{array}{c}0.298^{\star * *} \\
(4.67)\end{array}$ & $\begin{array}{c}0.3827^{\star * *} \\
(5.49)\end{array}$ & $\begin{array}{c}0.22497 \\
(0.72)\end{array}$ & $\begin{array}{c}0.4224^{* * *} \\
(5.8)\end{array}$ & $\begin{array}{c}0.333^{\star * *} \\
(3.63)\end{array}$ & $\begin{array}{c}0.205^{\star * *} \\
(4.74)\end{array}$ & $\begin{array}{c}0.136^{* * *} \\
(3.04)\end{array}$ \\
\hline $\ln \mathrm{Tp}$ & $\begin{array}{l}0.1264^{* * *} \\
(6.10)\end{array}$ & $\begin{array}{c}0.173^{\star * *} \\
(5.70)\end{array}$ & $\begin{array}{c}0.384^{\star * *} \\
(8.26)\end{array}$ & $\begin{array}{c}0.5073^{\star *} \\
(2.39)\end{array}$ & $\begin{array}{c}0.0723^{* * *} \\
(2.84)\end{array}$ & $\begin{array}{c}0.1154028^{\star * *} \\
(3.32)\end{array}$ & $\begin{array}{c}0.4983054^{* * *} \\
(11.40)\end{array}$ & $\begin{array}{c}0.605^{\star * *} \\
(13.34)\end{array}$ \\
\hline C & $\begin{array}{l}12.378^{\star * *} \\
(29.50)\end{array}$ & $\begin{array}{c}6.383^{\star * *} \\
(10.3)\end{array}$ & $\begin{array}{c}12.26^{\star * \star} \\
(10.5)\end{array}$ & $\begin{array}{c}6.29053 \\
(1.15)\end{array}$ & $\begin{array}{c}13.252^{* * *} \\
(17.96)\end{array}$ & $\begin{array}{c}6.643^{\star * *} \\
(7.06)\end{array}$ & $\begin{array}{c}9.687^{\star * *} \\
(21.2)\end{array}$ & $\begin{array}{l}4.95^{\star \star \star} \\
(9.02)\end{array}$ \\
\hline $\mathrm{R}^{2}$ & 0.4558 & 0.2656 & 0.7892 & 0.2581 & 0.4473 & 0.2157 & 0.9724 & 0.764 \\
\hline $\mathrm{F}$ & 67 & 28.93 & 52.41 & 10.61 & 28.32 & 31.25 & 90.31 & 297.1 \\
\hline Applicable mode & $\mathrm{FE}$ & $\mathrm{FE}$ & $\mathrm{FE}$ & $\mathrm{RE}$ & $\mathrm{FE}$ & $\mathrm{RE}$ & $\mathrm{FE}$ & $\mathrm{RE}$ \\
\hline Sample size & 270 & 270 & 50 & 50 & 120 & 120 & 100 & 100 \\
\hline
\end{tabular}

Note: ${ }^{*}{ }^{* *}$, and ${ }^{* * *}$ represent significance at $10 \%, 5 \%$, and $1 \%$, respectively.

$\mathrm{R} \& \mathrm{D}$. In addition, the total costs of enterprises have increased, and the benefits brought about by technological innovation cannot compensate for the increase in costs caused by environmental regulations. Therefore, the implementation of strict environmental regulations by the government and other relevant departments has not stimulated green innovation activities.

\subsubsection{Impact of Environmental Regulations on GTI in Heavily Polluting Industries}

From Table 5, we can see that for heavily polluting industries, including ferrous metal smelting and rolling processing, paper and paper products, non-metallic mineral products, chemical raw materials and chemical products manufacturing, non-ferrous metal smelting and rolling processing, the regression coefficient for the impact of environmental regulations on green process innovation is -2.060824 , at $5 \%$ significance. This indicates that environmental regulations have a significant negative impact on green process innovation in heavily polluting industries. Similarly, in heavily polluting industries, the regression coefficient of the impact of environmental regulation on green product innovation is -4.408068 , but is insignificant, indicating that environmental regulation has a non-significant negative impact on green product innovation. The implication is that stronger environmental regulation will inhibit the implementation of green process innovation and green product innovation in heavily polluting industries. This result also verifies, to some extent, the conclusion for the previous sample of industries in the manufacturing industry. 


\subsubsection{Impact of Environmental Regulations on GTI in Moderately Polluting Industries}

From Table 5, we can see that for the medium polluting industries, the regression coefficient of the impact of environmental regulations on green technology innovation is -2.306641 , and significant at $1 \%$, which indicates that environmental regulations have a significant negative impact on the green process innovation of moderately polluting industries. The regression coefficient for the impact of environmental regulation on green product innovation in moderately polluting industries is -0.9614285 , but not significant, indicating that environmental regulation also has a negative impact on green product innovation in moderately polluting industries. This is also consistent with the previous conclusions.

\subsubsection{Impact of Environmental Regulations on GTI in Lightly Polluting Industries}

As shown in Table 5, the regression coefficients of the impact of environmental regulations on green process innovation and green product innovation in lightly polluted industries are -0.2365437 and -0.2180703 , respectively, but are not significant, indicating that environmental regulations have a negative effect on green technology innovation in lightly polluted industries, which is also consistent with the previous conclusions.

From the above analysis, we can see that for the 27 manufacturing industries investigated, the Porter Hypothesis is not valid; there is a notional compliance cost of environmental regulation on green technology innovation. This also highlights the characteristics of these 27 manufacturing industries as obviously cost driven. Strict environmental regulation policies have not only failed to promote green technological innovation among these industries, but they have increased pollution control costs and engendered a squeeze effect on R\&D funds, thereby restricting their technological innovation activities.

\subsubsection{Impact of Various Control Variables on GTI}

As shown in Table 5, we can see that looking either at the full sample of the 27 manufacturing industries or separately at the heavily polluting industries, moderately polluting industries, or lightly polluting industries, the two control variables, innovative human resources investment and total profit have a positive and largely significant impact on innovations in both green processes and green products. The implication is that industries with higher total profits and more investment in innovative human resources are more conducive to GTI.

\section{Robustness Test}

From the results, we can see that the empirical results do not change significantly between looking at the full sample of the manufacturing industry or a sub-sample of the heavily polluted, moderately polluted, or lightly polluted industries. To further ensure the estimation results are robust, we selected a lag period for each explanatory variable to replace the current term and used model 
(1) and model (2) again for fixed and random effects. The results are used to verify the robustness of the models.

It can be seen from the results in Table 6 that for the full sample of manufacturing, environmental regulation still has negative effect on GPSI and GPTI, this result is roughly the same as that in Table 5. In addition, the influence coefficients of each control variable on GPSI and GPTI are all positive, and compared with Table 5, the values have little change. In summary, it can be shown that our results are robust.

\section{Conclusions and Recommendations}

\subsection{Conclusions}

The growth in the manufacturing industry has significant negative environmental externalities. Can the implementation of strict environmental regulations promote innovation in green technology in the manufacturing industry and achieve green and ecological development? This paper focused on the two dimensions of green process innovation and green product innovation. We selected panel data of 27 manufacturing industries from 2006 to 2015. From the perspective of industry heterogeneity, we empirically analysed the impact of environmental regulations on green technology innovation across these industries. We found that under the two control variables, total industry profits and innovative human resources investment, government formulated strict environmental regulation policies have created a certain degree of restraint on both green product innovation and green process innovation. This is mainly because, first, China's market economy has had a relatively short development time, and a mature market mechanism has not yet been formed. Although the manufacturing industry has been facing external pressures from strict government environmental policies, in the course of its development, its technological innovation

Table 6. Robustness test results.

\begin{tabular}{|c|c|c|}
\hline \multirow[b]{2}{*}{ Variable } & \multicolumn{2}{|c|}{ Manufacturing sample } \\
\hline & model (1) & model (2) \\
\hline ER & $-0.6940298^{* * *}(-3.98)$ & $-0.7538156^{* * *}(-3.26)$ \\
\hline $\operatorname{lnIMI}$ & $0.13249^{* *}(2.66)$ & $0.0448973(0.68)$ \\
\hline $\operatorname{lnTp}$ & $0.0601193^{* *}(2.44)$ & $0.0788088^{* \star}(2.41)$ \\
\hline $\mathrm{C}$ & $12.89129^{* * *}(43.72)$ & $7.584816^{\star * \star}(19.38)$ \\
\hline $\mathrm{R}^{2}$ & 0.1934 & 0.4714 \\
\hline $\mathrm{F}$ & 16.40 & 8.54 \\
\hline Applicable mode & $\mathrm{FE}$ & $\mathrm{FE}$ \\
\hline Sample size & 270 & 270 \\
\hline
\end{tabular}

Note: ${ }^{*},{ }^{*}$, and ${ }^{* *}$ represent significance levels at $10 \%, 5 \%$, and $1 \%$, respectively. 
has increased. However, the companies have not yet been able to offset the increased costs from regulation through greater profits in the market. Therefore, companies have no inherent driving motivation for green technology innovation. Second, enterprises need significant capital and personnel to carry out technological innovation activities. Thus, the implementation of strict environmental regulations by the government has increased the cost of pollution control for enterprises and simultaneously limited their funds for investing in production. This leads to a crowding out effect on R\&D funds, which therefore, has a negative effect on green technological innovation activities [23]. Finally, for most traditional manufacturing industries due to the lack of capital and technology required in the early stage of innovation, these industries have neither the ability nor the willingness to carry out technological innovation in the short term when faced with strict government environmental regulations and policies. Therefore, this has also inhibited green technology innovation activities to a degree.

Based on this, we offer the following suggestions:

1) The government should evaluate the actual situation and formulate positive and reasonable environmental regulation policies in this context. We can see from our results that the current government environmental regulation measures are indeed an important factor affecting GTI in these manufacturing industries-namely, strict environmental regulation policies have somewhat inhibited GTI activities in these industries. To change this, the government will need to relax the intensity of some environmental regulations. If the current approach continues, pollution control costs will continue to increase and crowd out innovation investment, thereby further restricting green technology innovation activities in these manufacturing industries.

2) As the government implements environmental regulatory policies and strengthens environmental governance and control on polluting emissions, it also needs to formulate corresponding fiscal, tax, financial, and talent policies. This means implementing certain fiscal or tax subsidies that can support the development of green technology innovation in the manufacturing industry and promote increased investment in innovation resources to achieve product transformation and technology upgrades.

3) The manufacturing industry has played a pivotal role in the sustainable development of the national economy. However, among manufacturing enterprises, a sustainable business development philosophy and innovation awareness need to be established to enhance green technology innovation capabilities. We should be aware of the necessity and urgency of implementing green technology innovation strategies, to change our business models to further strengthen the $\mathrm{R} \& \mathrm{D}$ for green products. This will promote the introduction and transformation of green process technologies and enhance green technology innovation abilities.

\subsection{Research Limitations and Future Directions}

Although this study offers several contributions to the literature, it also has limi- 
tations. First, the sample period is relatively short. This study uses the panel data from 2006 to 2015, which is relatively short period and the conclusion may not be comprehensive. Second, the scientific validity of selecting indicators needs further improvement. At present, there is still no agreement in academic circles on the selection of variables such as environmental regulation, green product innovation and green process innovation. Due to limited conditions, it is not possible to test each alternative index. This study adopts the alternative index common in the literature to measure the variables. Last, this study did not consider the differing impact of various environmental regulation tools on green technology innovation. Environmental regulations include command-and-control environmental regulations, market incentive environmental regulations and voluntary participation environmental regulations. Each type of environmental regulation will have considerably different impacts on enterprises' green process innovation. This is one direction that will be pursued in future research.

\section{Author Contributions}

J.L. coordinated the project and drafted this paper. M.Z. provided conceptual comments and contributed to revising the article.

\section{Funding}

This research was funded by Humanities and Social Sciences Funding Projects of Anhui Province (SK2020A0024); Fundamental scientific research funds for the central universities (B200207041); Fundamental scientific research funds for the central universities (B200207002).

\section{Conflicts of Interest}

The authors declare no conflicts of interest regarding the publication of this paper.

\section{References}

[1] Wang, F.Z. and Jiang, T. (2015) The Impact of Environmental Regulation on Green Technology Innovation in Resource-Based Industries-Based on the Perspective of Industry Heterogeneity. Research on Financial and Economic Issues, No. 8, 17-23.

[2] Poter, M.E. and van der Linde, C. (1995) Toward a New Conception of the Environment-Competitiveness Relationship. Journal of Economic Perspectives, 9, 97-118. https://doi.org/10.1257/jep.9.4.97

[3] Yu, W., Chen, Q. and Chen, H. (2017) Environmental Regulation, Technological Innovation and Business Performance: An Empirical Analysis Based on 37 Industrial Industries. Scientific Research Management, 38, 18-25.

[4] Li, W.H., Bi, K.X. and Sun, B. (2013) Impact of Environmental Regulation Strength on Green Technology Innovation in Pollution-Intensive Industries-An Empirical Test Based on Panel Data from 2003 to 2010. Research and Development Management, 25, 72-81.

[5] Levinsohn, J. and Petrin, A. (2003) Estimating Production Functions Using Inputs 
to Control for Unobservables. Review of Economic Studies, 70, 317-342. https://doi.org/10.1111/1467-937X.00246

[6] Slater, J. and Angel, I.T. (2000) The Impact and Implications of Environmentally Linked Strategies on Competitive Advantage: A Study of Malaysian Companies Research. Journal of Business, 47, 75-89. https://doi.org/10.1016/S0148-2963(98)00053-8

[7] Wagner, M. (2007) On the Relationship between Environmental Management, Environmental Innovation and Patenting: Evidence from German Manufacturing Firms. Research Policy, 36, 1587-1602. https://doi.org/10.1016/j.respol.2007.08.004

[8] Ramanathan, R., Black, A., et al. (2010) Impact of Environmental Regulations on Innovation and Performance in the UK Industrial Sector. Management Decision, 48, 1493-1513. https://doi.org/10.1108/00251741011090298

[9] Zhao, X.K. (2003) Environmental Protection and Industrial International Competitiveness: Theoretical and Empirical Analysis. China Social Sciences Press, Beijing, 110-113.

[10] Xie'e (2008) Environmental Regulation and China's Industrial Productivity Growth. Industrial Economics Research, No. 1, 22-28.

[11] Lanoie, P., Patry, M. and Lajeunesse, R. (2001) Environmental Regulation and Productivity: New Findings on the Porter Hypothesis. Working Paper.

[12] Liu, J.L. and Ran, M.S. (2015) Study on the Impact of Environmental Regulation on Industrial Production Technology Progress. Scientific Research Management, 36, 107-114.

[13] Jiang, F.X., Ji, Y. and Bai, J.H. (2014) The Relationship between the Intensity of Environmental Regulation and the Technological Progress of Industrial Enterprises-An Empirical Study Based on Threshold Regression. Modern Economic Research, No. 11, 39-43.

[14] Zhang, Q. (2016) Impact Mechanism and Empirical Research of Environmental Regulation on Technological Innovation of Enterprises. Harbin Institute of Technology, Harbin.

[15] OECD (2005) The Measurement of Science and Technology Activities. Oslo Manual: Guidelines for Collecting and Interpreting Innovation Data. OECD Publishing, Luxembourg.

[16] Sterner, T. and Turnheim, B. (2009) Innovation and Diffusion of Environment Technology: Industrial $\mathrm{NO}_{x}$ Abatement in Sweden under Refunded Emission Payments. Ecological Economics, 68, 2996-3006.

https://doi.org/10.1016/j.ecolecon.2009.06.028

[17] Bi, K.X., Yang, C.J. and Huang, P. (2013) Study on the Regional Differences and Influencing Factors of China's Green Process Innovation Performance. China Industrial Economy, No. 10, 57-69.

[18] Smarzynska, B.W. and Wei, S.J. (2001) Pollution Havens and Foreign Direct Investment: Dirty Secret or Popular Myth? CEPR Discussion Papers 2966, London. https://doi.org/10.3386/w8465

[19] Fredriksson, P.G. and Millimet, D.L. (2002) Is There a "California Effect" in US Environment Policy Making. Regional Science and Urban Economics, 32, 737-764. https://doi.org/10.1016/S0166-0462(01)00096-5

[20] Cole, M. and Elliott, R. (2003) Do Environmental Regulations Influence Trade Patterns? Testing Old and New Trade Theories. The World Economy, 26, 1163-1186. 
https://doi.org/10.1111/1467-9701.00567

[21] Nie, G.Q. and Guo, X.D. (2018) The Impact of Environmental Regulations on the Innovation and Transformation of China's Manufacturing Industry. Economic Geography, 38, 110-116.

[22] Ren, S.G., Hu, X. and Yuan, B.L. (2016) Research on the Staged Differences and Industrial Heterogeneity of the Impact of China's Manufacturing Environmental Regulations on Technical Innovation. Science \& Technology Progress and Policy, 33, 59-66.

[23] Jiang, F.X., Wang, Z.J. and Bai, J.H. (2013) Dual Effects of Environmental Regulation on Technological Innovation: An Empirical Study Based on Dynamic Panel Data of Jiangsu Manufacturing Industry. China Industrial Economy, No. 7, 44-55. 